\title{
Controle Jurisdicional da Adminustração pelo Recurso de Excesso de Poder
}

\author{
FRANÇOIS GAZIER \\ ("Maître des Requês" do Conselho de Es- \\ tado, francês, ora no Brasil, como Professor \\ de Ciência Política da E.B.A.P.)
}

A "Revista do Serviço Público" tem a honra de apresentar, neste número bem como no seguinte, um estudo original do Professor FrançoIs GAzIER sôbre o regime francês de contrôle da legalidade administrativa, por meio do recurso de excesso de poder. $O$ autor, em razão das eminentes funções que exerce no Conselho de Estado, onde tem funcionado como "Comissaire du Gouvernent" ápice da judicatura administrativa, é autoridade na matéria. Estuda-a, por assim, em têrmos precisos, em estilo de meridiana clareza, e suǵestivo. Com essas qualidades, o presente estudo do Professor FrançoIs Gazier, escrito especialmente para esta Revista, representará a mais atualizada e fidedígna exposição sôbre assunto pràticamente desconhecido entre nós, qual seja o regime do contrôle jurisdicional da administração, fora do juiz comum.

$\mathrm{U}$

M dos caracteres do Estado moderno reside na submissão da administra. ção pública à regra de direito. A despeito de suas prerrogativas de poder público, a administração acha-se duplamente limitada pelos princípios de legalidade e de responsabilidade. Suas decisões não são válidas senão quando rigorosamente conforme ao direito em vigor. De outro modo, são passíveis de anulação. A ação administrativa só é legítima caso não provoque a outrem prejuízo injusto. Se êste ocorrer, deverá ser reparado. Daí a necessidade de juiz que tenha o poder de anular a atividade administrativa ilegítima e de reparar o prejuizo causado. O Estado moderno, sob qualquer estrutura em que se apresenta, possui por conseguinte, um regime de contrôle juridicional da administração pública.

Mas, qual será o juiz da administração? Neste ponto, diferem as soluções; opõem-se, principalmente, dois grandes sistemas, comumente chamados de unidade de jurisdição. Ou o contrôle da administração é confiado aos tribunais comuns, ou reservado à competência de jurisdições especiais . 
Curioso é notar que êsses dois sistemas se atribuem o princípio da separação dos poderes e decorrem assin, da mesma filosofia política. Julgar a administração constitui, com efeito, operação complexa que, por natureza, atinge o Poder Judiciário, e, por objeto, o Poder Executivo. Para alguns, o essencial está no caráter jurisdicional do contrôle sôbre a administração. Daí seu vínculo ao Poder Judiciário. Para outros, o que se impõe, de início, é a participação da função jurisdicional na ação administrativa em geral, donde o princípio de separá-la da função jurisdicional do judiciário, vinculando-a ao Executivo.

E' sabido que o sistema de unidade de jurisdição prevalece nos países anglo-saxões, na Inglaterra e nos Estados Unidos, principalmente, e o da dualidade de jurisdição encontra sua primeira e mais completa aplicação na França.

Sabe-se, igualmente, que o Brasil, após haver experimentado, de maneira muito incompleta aliás, o sistema de dualidade de jurisđição durante o Império, adotou, com a República, o regime de unidade jurisdicional. E' notório, enfim, que, em parte alguma, os dois sistemas são absolutamente exclusivos e estanques. Onde existe ordem jurisdicional administrativa distinta da ordem judiciária os tribunais comuns conservam sempre, em matérias excepcionais, competência para julgar a administração. $E$ onde a administração está sujeita, em princípio, ao juiz de direito comum, existem e tenderão existir, cada vez mais, jurisdições administrativas especializadas, formas de contencioso particular que permanece fora da hierarquia judiciária.

Mas, seja qual fôr o órgão que o exerça, o contrôle jurisdicional da administração exige sempre operações essenciais idênticas: anular e indenizar. A administração se distingue das emprêsas privadas não tanto pelo número de serviços que possui, pela importância das tarefas que executa, pelo poder dos meios de que dispõe mas, sobretudo, pelo fato de exercitar o poder jurídico de tomar decisões unilaterais e executórias. À ação em juízo que, nas relações entre particulares, conduz normalmente a determinada fórmula de indenização ou ressarcimento deve acrešcentar-se outro meio particular, de defesa de direito, fora do objetivo estrito da justiça comum, e tendente à anulação das decisões administrativas ilegais.

Um sistema completo de contrôle jurisdicional da administração, seja de ordem judiciária, ou administrativa, deve, necessàriamente, comportar, pelo menos, dois recursos: um de indenização, outro de anulação, sendo êste mais original porque não tem correspondência material no processo civil ordinário.

E' no sistema francês de dualidade de jurisdição que vamos encontrar o primeiro exemplo e, segundo a opinião universal, o mecanismo mais perfeito do recurso de anulação, assim entendido. Trata-se do recurso de excesso de poder do contencioso administrativo francês.

E' nosso propósito evocar-lhe, aqui, a origem e desemvolvimento, precisar-lhe as condições de admissão e de mérito e indicar-lhe os efeitos. A seguir, à guisa de conclusão, traçaremos um paralelo entre o recurso de excesso de poder francês e o mandado de segurança, instituição fundamental do contrôle da legalidade dos atos administrațivos, no Brasil. 


\section{I - ORIGEM E DESENVOLVIMENTO DO RECURSO DE EXCESSO}

DE PODER

O recurso de excesso de poder não saiu inteiro e completo do cérebro de um jurista ou de um legislador. E' êle obra empírica, paulatina, progressiva de uma jurisdição administrativa: o Conselho de Estado francês.

Herdeiro do Conselho do Rei, cuja origem remonta à "Curia Regis", que assistia os primeiros reis capetos, o Conselho de Estado foi instituído por $\mathrm{Na}$ poleão em $1800 \mathrm{com}$ a triple missão de redigir os projetos de lei, dar pareceres sôbre numerosas questões administrativas e julgar questões entre a administração e os particulares. Nesta última função, o Conselho de Eștado não atuava, no início, como tribunal. Propunha apenas ao Chefe de Estado uma solução que êste, a rigor, não era obrigado a adotar. Mas seus pareceres eram motivados como verdadeiros julgamentos e, pràticamente, sempre homologados, de modo que a transição, do regime de justiça pendente de homologação do Chefe do Estado para o de justiça delegada em que os tribunais administrativos passavam a decidir sobremandante, em nome do povo francês no último quartel do século XIX, apenas deu consagração periódica a um regime de fato de há muito aceito.

Assim, em sua missão contenciosa, o Conselho de Estado atuou, durante longo tempo, não só como superior hierárquico da administração mas ainda como órgão jurisdicional pleno. Êste último aspecto comporta o recurso de indenização, chamado também recurso de pleno contencioso, análogo à ação judicial intentada perante o juiz comum. Por sua vez, o primeiro aspecto caracteriza-se pelo recurso de anulação, ou recurso de excesso de poder, homologa à petição apresentada ao chefe de serviço, visando anular decisões irregulares de qualquer de seus subordinados. Quando, em 1872, o Conselho de Estado foi reconhecido como tribunal soberano, o recurso de excesso de poder já ocupava no contencioso administrativo posição tão importante quanto o recurso de pleno contencioso. Um e outro constituíam os dois pilares do contencioso administrativo francês. Com o correr do tempo, o equilíbrio entre os dois recursos se manteve. Certos autores ousavam às vêzes prever a absorção do recurso de excesso de poder pelo recurso de pleno contencioso (HAURIOU), ou, inversamente, do recurso de pleno contencioso pelo de excesso de poder (ALBERT). Essas profecias não se realizaram. Os dois recursos subsistem nitidamente distintos, e o recurso de excesso de poder, hoje consagrado por textos legislativos, conservou tôda a vitalidade e originalidade. Como tal, bem representa a mais bela criação do contrôle jurisdicional da administração na França.

Surgindo no Conselho de Estado, idealizado, desenvolvido, aplicado por êle, o recurso de excesso de poder ali permaneceu por muito tempo como remédio exclusivo. Até data recente, o Conselho de Estado reservava-se, por assim dizer, o monopólio de anulação dos atos administrativos de qualquer autoridade, por mais humilde que fôsse. As outras jurisdições administrativas, tôdas submetidas, aliás, ao Conselho de Estado por via de apelação ou por via de cassação, pndiam, dentro dos limites da própria competência, condenar a administração, mas não tinham poder para the anular, com efeito 
absoluto, as decisões, por insignificantes que fôssem. E' que por muito tempo se considerou que o poder de anulação constituia uma espécie de prerrogativa que sòmente se poderia atribuir a um corpo único, situado no ápice da administração francesa e herdeiro de uma tradição judiciária, administrativa e governamental multi-secular.

Foi o próprio triunfo do recurso de excesso de poder que impôs a modificação do sistema. Sob o alvo flagrante da confiança dos postulantes, o Conselho de Estado não conseguia mais julgar os milhares de recursos que the eram submetidos. De ano a ano acumulava-se o número dos processos atrazados. A justiça administrativa era distribuída em câmara lenta. Impunha-se reformá-la. Foi o que se tentou fazer a princípio, timidamente, em 1934. Os Conselhos de Prefeitura, jurisdições administrativas locais incumbidas até então, de julgar, em primeira instância, os litígios surgidos na execução das obras públicas e na cobrança dos impostos diretos, tornavam-se competentes para anular as decisões administrativas ilegais referentes à aplicação do estatuto dos funcionários locais. Era a primeira brecha no monopólio do Conselho de Estado em matéria de recurso de excesso de poder.

\section{II - A ADMISSIBILIDADE DO RECURSO DE EXCESSO DE PODER}

O recurso de excesso de poder é, pois, um meio jurídico tendente à anulação dos atos administrativos ilegais. E' evidente que êle não é interposto em qualquer tempo, em favor de qualquer pessoa, ou contra qualquer ato administrativo. Antes mesmo de examinar se o recurso tem fundamento, isto é, se êle denuncia efetivamente uma ilegalidade capaz de provocar a anulação do ato incriminado, o juiz deve verificar se é admissivel; se atende às condições para ser regularmente interposto. São quatro as condições de admissibilidade: o requerente deve justificar certo interêsse pela anulação dơ ato; o recurso deve ser interposto dentro de certo prazo; o ato impugnado deve ser ato administrativo executório; enfim, não deve existir recurso paralelo, conduzindo ao mesmo resultado procurado pelo postelante.

\section{Interêsse pela Anulação do Ato Administrativo}

O recurso de excesso de poder não constitui sòmente uma garantia ao cidadão contra as conseqüências de decisão administrativa ilegal. E', igualmente, medida de saneamento jurídico destinada a escoimar o direito positivo em vigor das prescrições irregulares que o eivam.

Poder-se-ia admitir que, oposto ao princípio do processo civil, segundo o qual "não havendo interêsse não há ação" e é preciso justificar a denegação de direito para agir em justiça, o recurso de excesso de poder aproveita a qualquer cidadão vigilante que tome a iniciativa de denunciar uma ilegalidade, mesmo no caso de não ser pela mesma perturbado. Seria uma espécie de ação popular, como a conheceu o direito ramano. Mas uma tal concepção apresentaria o duplo inconveniente de entravar, sem motivo plausível, o funcionamento dos serviços públicos e de sobrecarregar de trabalho os tribunais administrativos. Assim, é de regra que o requerente, sem precisar justificar a lesão de direito, tenha não obstante, de motivar o interêsse que o leva a agir. 
E' necessário que a decısão em lide the haja provocado algum dano material ou moral.

A jurisprudência atual apresenta-se, aliás, extremamente liberal na apreciação do interêsse do postulante. Inicialmente, é necessário ocorra um interêsse individual, como o que provoca a ação do proprietário contra recusa do direito de construção; o interêsse do comerciante para anular decisão que regulamente o estacionamento de veículos em sua rua; o de industrial, contrário à majoração arbitrária dos salários; o do funcionário contra sanção disciplinar ou nomeação de colega para o cargo pelo postulante ambicionado.

E' possível também invocar o interêsse coletivo. Uma associação ou um sindicato podem interpor recursos contra medidas que ataquem individualmente um de seus membros. Um contribuinte pode alegar esta qualidade para contestar as decisões onerosas de uma assembléia local. O eleitor pode requerer a anulação de medida administrativa preparatória das eleições. O crente pode investir contra a interdição de uma cerimônia religiosa. Enfim, as autoridades da administraçäo descentralizada (Departamento, Comuna, estabelecimento público) podem interpor o recurso de excesso de poder contra decisões da autoridade de tutela.

\section{O prazo de interposição do recurso}

Anular, com efeito absoluto e retroativo, decisão administrativa ilegal causa sempre algumas perturbações na atividade dos serviços e colide, por vêzes, com situações legitimamente constituídas. E' preciso, pois, que a ameaça đe anulação não pese indefinidamente sôbre tôdas as decisões administrativas. Há um momento em que a possível injustiça é preferível à desordem, em que as situações constituídas não devem mais causar perturbações. Tal é a razão por que o recurso tem de ser interposto dentro de determinado prazo. Expirado êste, deixar de ser admissível, não podendo ser conhecido. $\mathrm{O}$ ato, mesmo ilegal, torna-se irretratável; consolidar-se-á contra o possível autor, que não poderá intentar-1he a anulação.

O prazo de interposição é, em princípio, de dois meses, contados, ora a partir đa publicação do ato, ora a partir da data de notificação. A adminıstração compete provar o cumprimento de uma ou de outra dessas formalidades. Si negligenciou neste particular, não correrá o prazo e a decisão permanecerá sempre suscetível de anulação.

Certas circunstâncias (interposição de recurso gracioso perante o autor do ato impugnado, ou perante superior hierárquico; pedido de assistência judiciária; conhecimento do pedido por jurișição incompetente) podem prorrogar o prazo, que poderá, também, ser reexaminado em casos excepcionais (mudança importante na legislação, na jurisprudência ou nas circunstâncias do fato).

\section{A natureza do ato impugnado}

O recurso de excesso de poder é admitido, em princípio, contra tôdas as decisões executórias que emanam das autoridades administrativas francesas. A jurisprudência do Conselho de Estado precisa, com exatidão meticulosa, os limites dêsse vasto domínio. 
Necessário é, antes de tudo, que a decisão impugnada seja de autoridades francesas. Não se pode utilizar o recurso de excesso de poder, se aquela autoridade estiver associada a outra soberania. (Marrocos, Tunísia, Vietnam....)

De outro lado, o recurso só é admissível contra decisão de autoridades inerentes ao Poder Executivo (Presidente da República, Presidente do Conselho, Prefeitos, (Maires), funcionários civis e militares). As decisões das Assembléias Legislativas ou das autoridades judiciárias, mesmo quando referentes a assuntos administrativos, ficam fora do domínio do recurso de excesso de poder. O mesmo acontece relativamente a certas decisões de autoridades que, embora se coloquem no plano administrativo, atuam, seja como órgãos governamentais (teoria dos "atos de govêrno"), seja como simples particular, na gestão de seu patrimônio (teoria da gestão privada).

Sob outro aspecto, o recurso só é admissível, se o ato impugnado emana realmente de uma autoridade pública e não de organismo privado. Ora, precisar a fronteira entre um e outro torna-se, dia a dia, mais difícil, tanto se desenvolveu a intervenção estatal na vida econômica e social do país (Sociedades do Estado, "régies" etc), como se expandiu a colaboração das emprêsas privadas na gestão dos serviços públicos (estabelecimentoz de utilidade pública, agrupamentos profissionais... etc.)

Enfim, o ato impugnado deve ter o caráter de decisão jurídica, unilateral e executória. Logo, o recurso de excesso de poder não é admissível ccntra a execução de contratos assinados pela administração, mas sòmente contra os atos de autorização, de aprovação ou de execução, nitidamente distintos do próprio contrato. E' ainda necessário que se trate realmente de decisão executória que produza, por si mesma, efeitos jurídicos. Simples operação, não traduzida em decisão escrita ou oral, intenção de agir, confirmação de providências, ou na simples medida de ordem interna sem repercussão fora do serviço não podem ser objetơ do recurso de excesso de poder.

As restrições podem parecer numerosas. Na verdade, não passam de fronteiras de um domínio jurisdicional extremamente vasto. Pràticamente, tôda a atividade administrativa francêsa, qualquer que seja a autoridade incriminada (desde o Presidente da República e o Presidente do Conselho ao mais humilde agente de execução administrativa, qualquer que seja o alcance da decisão em causa (desde o que decorre de decreto-lei aplicável como lei em todo o território, até a simples medida individual, de iniciativa da comuna menos importante); qualquer que seja a ordem de interêsse em jogo (civil, militar, econômico, financeiro, social... etc), - tudo incide no contrốle jurisdicional da administração por meio do recurso de excesso de poder.

\section{$A$ ausência de recurso paralelo}

Em virtude de sua origem puramente jurisprudencial, o recurso de excesso de poder se desenvolveu, assumindo caráter subsidiário que deu causa à teoria do recurșo paralelo. Isso significa que, se o requerente pudesse utilizar, para obter a anulação do ato, outro meio em justiça, perante um tribunal judiciário, ou, ainda, outro tribunal administrativo, ou mesmo, perante o próprio Conselho de Estado, o recurso de excesso de poder não era provido. Essa 
teoria está ainda em vigor, mas a jurisprudência, ao ampliar a análise dos atos distintos, no exame de uma operação juríaica complexa (tal como contrato expropriação, eleição) acabou por tornar cada vez mais rara a aplicação do princípiơ do recurso paralelo. Poderá acontecer que, de futuro, desapareça essa última condição de admissibilidade do recurso de excesso de poder.

\section{Forma do recurso de excesso de poder}

O recurso por excesso de poder não está sujeito a nenhuma forma processual obrigatória, e é pràticamente gratuito. Prescinde de advogado e, baseado em processo escrito, não obriga o requerente a comparecer perante o tribunal, nem a se fazer representar em juízo. Fica sujeito o postulante sòmente ao pagamento de direitos fiscais mínimos: requerimento redigido em papel timbrado; em caso de não provimento de recurso, e apenas por ocasião dı rejeição, pagamento da taxa de registro. Difícil é, pois, imaginar processu mais econômico e menos formalístico.

A essas qualidades não reune, infelizmente, o recurso a vantagen đ̛a rapidez. E' assim que, se reforma do contencioso administrativo levada a efeito em 1953, não vier anular o atraso de pedidos acumulados perante . Conselho de Estado, a duração média de julgamento do recurso de excessu de poder permanecerá infelizmente sensivel, ainda por muito tempo.

(Conclusão no próximo número)

Plantar simpatias, semear boa vontade, inspirar sentimento de respeito e estima, estabelecer bases de entendimento, criar disposições favoráveis, numa palavra, conquistar o animus collaborandi do público em geral e das clientelas da respectiva om. prêsa em particular - eis o objetivo constante e final de um serviço de Relações Públicas.

Benedito Silva in Relações Públicas, Divulgacão e Propaganda Cadernos de Administração Pública - "Fundação Getúlio Vargas". 